\title{
Service Learning: Bringing The Business Classroom To Life
}

\author{
Lauren Ayers, Student, West Virginia University, USA \\ Tristan L. Gartin, Student, West Virginia University, USA \\ Brannan D. Lahoda, Student, West Virginia University, USA \\ Shannon R. Veyon, Student, West Virginia University, USA \\ Megan Rushford, Student, West Virginia University, USA \\ Presha E. Neidermeyer, West Virginia University, USA
}

\begin{abstract}
While service-learning may be easily incorporated into medical or legal fields, this type of active learning generally has not been historically integrated into any discipline within the business curriculum. This is unfortunate, as the utilization of business students in not-for-profit environments can provide a triple-win scenario: the students receive an enriched learning experience, as they likely will confront opportunities at the entry level that are not generally experienced until the middle-management level; the administrators at the not-for-profit have access to business students with skills that are necessary but typically expensive to acquire; and the constituents served by the organization are enriched by having improved delivery or efficiency of service. Within this paper, we will discuss the service-learning environment and will then detail a project we have worked on in a service-learning-oriented class, with the hope that others may use our experience to facilitate their own service-learning projects as students or within the context of a class.
\end{abstract}

Keywords: Service learning, Service learning projects

\section{INTRODUCTION}

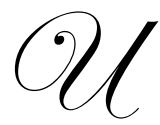

pon completion of an undergraduate education, it is not uncommon for students to wonder how they will translate countless classroom concepts into real-world situations. Service-learning could quite possibly one answer. Service-learning is "a teaching and learning strategy that integrates meaningful community service with instruction and reflection to enrich the learning experience, teach civic responsibility, and strengthen communities" (Learn and Serve Clearinghouse, 2010). Engaging college students in active servicelearning not only benefits the students, but has an impact on the community and the institution of higher learning. This differs from community service in that education and service are both emphasized. These aspects are meant to complement one another.

Business students are often encouraged to think about solutions to real-world problems; but these solutions rarely find themselves applied in actual businesses. Service-learning is a way for students to see their ideas in action, as well as a way to benefit not-for-profit organizations. All disciplines of business could implement servicelearning. Through our experiences, we believe the relationships forged and lessons learned through service-learning can be life-long and very productive.

Service-learning allows instructors and students to develop a type of relationship that would be difficult to attain in a traditional classroom setting, by providing the opportunity for the student and instructor to explore ideas and issues that would not otherwise be discussed. This creates an environment in which the instructor and student learn from one another. Moreover, service-learning strengthens the relationship that the college or university has within the community and that the institution has with various local organizations. These relationships benefit all parties, helping to meet the needs of the community while allowing the educational institution to focus on active 
community involvement. This connection will inevitably foster a future committed to civic involvement by the students through the emotional ties they form while working with an organization.

The skills business students possess are varied, and this can be useful to not-for-profits. Often, not-forprofits may be unable to obtain the services they need due to their expensive nature. The opportunities that a notfor-profit can offer students often exceed those that would be encountered in an entry-level position, and this allows the students to expand their skills and perfect competencies already in place. This allows the students not only to use their educations to-date and to augment it through interaction with professionals in the organization and by using the instructor as a sounding-board for issues and ideas. Similarly, the organization benefits from the skills the students possess in more than one way: the skills provided might be new to the organization and the organization can learn how to perform those new tasks, while the individuals the organization aims to help will ultimately benefit from improved service.

While service-learning is often integrated into other fields of study, its inclusion in the business curriculum, unfortunately, is rare. The wealth of knowledge students encounter in such programs prepares them for the world they will enter upon graduation. While the traditional in-class accounting courses provide a core knowledge via a structured approach to the material, by participating in service-learning, students encounter unstructured problems much like those they will confront on the job, which encourages them to integrate all aspects of their fields. Additionally, this type of learning enhances students' professional skills for constructing client relationships and working within a team setting. All stakeholders to the enterprise benefit from the work performed by the students. It is our hope that more courses will incorporate service-learning components.

\section{SERVICE-LEARNING FOR BUSINESS STUDENTS}

\section{Accounting}

Accounting information systems provide one avenue for accounting students to get involved in servicelearning. Many businesses and organizations need help creating such a system or may just need help updating their current system. If an organization is using a manual system, students could help the organization implement an automated process; if an organization is using unsophisticated or outdated software, students could recommend another system and aid in the transition process. Both activities may include helping to train new employees on aspects of the new program. Often, it is best to find start-up firms or organizations within the community who may not be able to afford professional accounting and tax services. Not-for-profits are ideal examples of these types of firms, as these organizations can often use help with selecting software and establishing accounts as well as preparing statements, tax returns, depreciation schedules, and monthly reports. Such assistance with accounting information systems provides excellent opportunities for students to receive hands-on training for systems that they have studied in class and prepares them for professional consulting services after graduation.

Another way for accounting students to get involved is through collaboration with the IRS Volunteer Income Tax Assistance Program (VITA). This program provides free tax preparation and support to qualified individuals through community volunteers (e.g., accounting students) who are trained to provide these services. VITA sites are often located within schools, shopping malls, libraries, and other convenient locations. The program offers assistance to low to moderate income individuals with gross income below $\$ 49,000$ (Internal Revenue Service, 2010), and is an excellent way for students to receive training in tax preparation and help others through the tax-preparation process. Not only will this strengthen the students' preparation skills, but they will be faced with situations that will augment and solidify their in-class experience obtained via traditional textbook work and case studies. The students also will learn to communicate better with clients as they explain the returns and corresponding implications.

Accounting students can further enhance communication skills, as well as their financial education, by offering workshops to residents in low-income areas on topics such as household finance and budgeting. Student workshops could be held at local school districts. For example, college students could give presentations to high school students about their financial futures regarding credit cards, student loans, and the ways scholarship, grant, and loan money impacts tax returns and personal budgets. All of the se workshop suggestions would require a 
student to research the topic and explain it to others. Giving the presentation would prepare accounting students for professional research, public speaking, and client interaction.

\section{Finance}

One type of service-learning project that business students in a financial concentration could assist with is microlending, which consists of extending small amounts of money to people in poverty to help encourage individual entrepreneurship in communities that do not generally qualify for traditional lines of credit. These types of loans are beneficial because they are not simply "hand-outs." Microloans give the recipients ownership and responsibility over their businesses. If the recipient is able to use the funds to create a sustainable business venture, they will be better able to provide for their family and become a cornerstone of the community providing much needed community life in rural or impoverished areas. Business professionals are needed to help with the selection of loan recipients and to educate those recipients on the requirements necessary to receive and repay such loans. Finance majors would be ideal candidates to assist in this area. Such involvement would entail a win-win-win scenario, whereby the student would have the opportunity to assist in the implementation and the education of the loan process increasing his/her marketability in the job market, the recipient of the loan would receive additional education and would be able to have the opportunity to receive a loan and make a living, and the not-for-profit granting the loan would have a positive payback through the loan and the subsequent increase in the living standards in the local community.

\section{Marketing}

Marketing offers a variety of service-learning projects where students can get involved with a local company or organization, assess that entity's needs, and develop a strategy for improvement. Businesses and organizations may need assistance promoting their images, products, or even company-sponsored events. Students can help with this by creating brochures, fliers, commercials, and newspaper or radio advertisements, for example. Students may be particularly adept at using some of the newer technology that might be overlooked by a more traditional organization or company. The development of Web 2.0, with its emphasis on social networking, creates new ways that a company can interact with its customers. These forms of social media include blogs and networking websites such as Facebook and MySpace. It may be beneficial for a company to become active in this type of media, especially when trying to reach certain target groups of customers. To promote a product or event, companies can advertise online within these forums, send messages to their followers and even receive feedback for improvement. Marketing students can be instrumental in developing a company presence in these areas of the World Wide Web.

Surveys and consumer research are another place where marketing students can get involved. Students can help a service organization run a survey to evaluate consumer attitudes towards its products and services, for example. They could conduct research to establish company benchmarks and to evaluate comparable service organizations. After the surveys and research are complete, marketing students could code and analyze the data and report the results to the company for use in forthcoming marketing efforts.

\section{Management}

Grant writing is one much-needed service that management students could perform as a service project. Given their futures as business leaders, they must be able to articulate goals and communicate them effectively, which is ultimately the objective of grant writing. The entire process of grant writing requires the ability to understanding and communicate an entity's objectives with the hope of obtaining external funding. Business students have both the quantitative and qualitative skills necessary to perform a process as detailed and researchoriented as grant writing.

Fund raising is another are of potential involvement for management students, who would be able to exercise their networking skills and put together a fund raising plan or perhaps even an event to benefit the not for profit organization. 


\section{Economics}

Given economics' inherently theoretical basis, service can help to bridge the gap between the theoretical and the practical for economics students. Service-learning in economics can take place on either a micro or macro level. Economics students can assist individual entrepreneurs in the community with business modeling, identifying market niches, and determining how best to fill them. A more ambitious project would be the economic revitalization of an entire community. Many communities nationwide have struggled during the economic downturn. Students may be able to help community leaders by offering fresh perspectives on the community's economic strengths and resources, possibility helping to craft a plan for economic revitalization. For example, West Virginia University's Extension Service's Community Design Team recently completed this type of economic project in Mount Hope and Union, West Virginia (WVU Today, 2010). Not only does this provide students with practical experience beyond that available in a classroom, but it constitutes a significant service to the community. Community design not only influences the health of a community and its citizens, but the well-being of the state as a whole.

\section{HOW TO INSTITUTE A SERVICE-LEARNING PROGRAM}

Before any service-learning project can be put in place, the institution, faculty, and students must realize the need for serving the community in which they work and live. Members of a university are stakeholders in their community, and, as Dr. Ira Harkavy, a professor at the University of Pennsylvania Center for Community Partnerships, has noted, "Universities cannot afford to remain shores of affluence, self-importance and horticultural beauty at the edge of inland seas of squalor, violence, and despair" (University of Pennsylvania Almanac, p. 10, 1995). This is true for institutions in both urban and rural settings, and it is in our opinion that all institutions of higher learning should commit to making better citizens of faculty and students while creating tangible improvements to the communities in which they reside. Drawing from our own experiences, as well as previous research from service-learning scholars, we have identified five crucial steps for successfully implementing a service-learning project into a higher education curriculum.

How to implement a program:

1. Identify the need for service

Prior to delving into any planning, the faculty and students should identify pressing community needs that are feasible and appropriate for a student team to address. To facilitate the most enthusiastic student participation possible, faculty should align the project idea with the interests of the students, while at the same time committing to an authentic learning experience (Berman p. 19, 2006).

\section{Secure a community partner}

Once the need is identified, faculty and student leaders must reach out to local organizations already committed to the particular community service. Many universities have administrative departments specifically focusing on student-based community service that have contacts readily available. West Virginia University's Center for Civic Engagement, for example, has relationships with more than 100 not-for-profit community service organizations. These relationships should be mutually beneficial to both the institution and the organization (Bringle and Hatcher p. 12, 2006).

\section{Plan and manage the process}

Once a community partner is identified and secured, the service-learning team should meet with the community partner to identify ways the team can help the organization achieve its goals. This should include planning the service to be done or the event to be organized. Faculty would do well at this stage to align the particular community service project to educational goals (Berman p. 17, 2006). 
4. Facilitate reflective student-learning throughout the process

Service-learning can do more than simply address the needs of the community — it can foster a lifetime love for and a commitment to service. As such, faculty should require students in a given project to reflect on their service-learning experiences throughout the process. This can be done via journal entries, team evaluations, and interactive Web discussions or scheduled meetings. At the conclusion of the project, faculty could require the student volunteers to write reflective essays or research essays about the project or present their experiences to peers, interested faculty, and community members.

\section{Institutionalize a spirit of service-learning}

Perhaps the most important step in the process of implementing a service-learning project is to build upon previous experiences and expand service-learning initiatives across the institution. An ideal scenario would be to make service-learning a part of an institution's undergraduate curriculum.

\section{GENERAL CONCLUSIONS}

It is our opinion that business students need to be involved with service-learning projects. As we have seen, projects are available to business students with an interest in learning more about their specific fields. Quickbooks, budgeting, microloans, and marketing strategy projects could and should be made available to students who have a desire to gain this valuable real-world experience. Fundraising opportunities provide direct sales-related experience. The ability to write and understand monetary grants is necessary for a career in academia or public service. Thus, service-learning programs give business students a better grasp of future career opportunities while opening doors in the not-for-profit sector. These opportunities allow students to gain relevant professional experience as undergraduates, while offering benefits to both the not for profit and their clientele. Such beneficial opportunities should not be overlooked when evaluating and changing the curriculum at institutions of higher learning with a desire to help their communities.

\section{AUTHOR INFORMATION}

Lauren Ayers is a senior accounting major at West Virginia University. She will graduate with her Bachelor's degree in December 2010. During the upcoming summer of 2010, Lauren will be participating in the PricewaterhouseCoopers internship program, and she is involved with many on-campus student organizations.

Tristan Gartin is a senior accounting major at West Virginia University. She is a West Virginia Promise Scholar and a WVU Foundation Outstanding Senior. Upon graduation, she will pursue a Master's Degree in Human Resources and Industrial Relations at West Virginia University. She enjoys international travel and has pursued notfor-profit work in Africa, which she intends to continue in the future.

Brannan D. Lahoda is a dual major of Economics and Finance at West Virginia University. He is the Opinion Editor for The Daily Athenaeum, WVU's official student newspaper and a member of student government. In addition to business topics, his academic interests include geography and political science. Upon graduation, he plans to enroll in a graduate program in public policy. In his spare time, he enjoys playing basketball and tennis as well as writing short stories.

Megan Rushford is a senior accounting major at West Virginia University. She will graduate with a degree in Business Administration in May 2010. During undergraduate school, Megan has been employed at a local CPA firm. After graduation, she plans to return to WVU to earn a Master's in Professional Accountancy while continuing to work.

Shannon R. Veyon is senior accounting major in the honors program and is involved in numerous campus organizations at West Virginia University. During the summer of 2010, she will be interning with PricewaterhouseCoopers. She plans on becoming a CPA, working in the field of taxation, and being active in global philanthropic efforts. She assists a local high school softball team, works with Habitat for Humanity, and writes children's stories for magazine publication. 
Presha E. Neidermeyer is an associate professor of accounting in the College of Business and Economics at West Virginia University. She is actively involved with service learning projects including the WVU College of Business and Economics Honors Capstone Project and the WVU VITA program. She works with various charities in Africa and will be returning to Malawi in August of 2010 along with several students to begin a microlending program.

\section{REFERENCES}

1. Berman, S. (2006). Service learning: a guide to planning, implementing, and assessing student projects. Thousand Oaks, CA: Corwin Press.

2. Bringle, R.G., \& Hatcher, J.A. (1996). Implementing service learning in higher education. Journal of Higher Education, 67(2), 12.

3. Bryant, A., \& McCoskey, M. G. (n.d.). Service Learning in Accounting Education: A Student's and a Professor's Perspective. Retrieved April 20, 2010, from

http://www.newaccountantusa.com/newsFeat/wealthManagement/melanie na response to servicelearning.pdf

4. Giegerich, E. (2008, August 25). A Look at Tulane's service-learning post-Katrina. The Nation.

5. Harkavy to address urban issues. (1995). University of Pennsylvania Almanac, 42(3), 10.

6. Holtzman, D., Stewart, K. L., \& Barr, J. (2008). Service learning: theory and application to marketing and management. Journal of the Northeastern Association of Business, Economics \& Technology, 14(1), 7-13.

7. Internal Revenue Service. (2010, March 8). Free Tax Return Preparation For You by Volunteers. Retrieved April 20, 2010, from IRS.gov: http://www.irs.gov/individuals/article/0,,id=107626,00.html

8. Learn and Serve America's National Service-Learning Clearinghouse. (n.d.). Learn and Serve America's National Service-Learning Clearinghouse. Retrieved April 9, 2010, from http://www.servicelearning.org/

9. Tierney, J.P., Grossman, J.B., \& Resch, N.L. (1995). Making a difference: an impact study of big brothers big sisters. Private/Public Ventures, 22. 